\title{
A brief massive aggregation of pelagic swimming crabs Euphylax dovii (Decapoda: Portunidae) at Cocos Island, Costa Rica coincides with onset of EI Niño event
}

\author{
Alex Hearn ${ }^{1,2,3}$, Todd Steiner ${ }^{2,3}$ \& Randall Arauz ${ }^{2,4}$ \\ 1. Galapagos Science Center, Universidad San Francisco de Quito, Ecuador; ahearn@usfq.edu.ec \\ 2. MigraMar, Forest Knolls, CA, USA \\ 3. Turtle Island Restoration Network, Olema, CA, USA; tsteiner@tirn.net \\ 4. Fins Attached Marine Research and Conservation, CO, USA; rarauz@finsattached.org
}

Received 10-V-2019. C Corrected 22-V-2019. Accepted 20-VI-2019.

\begin{abstract}
Introduction: Sporadic aggregations of decapod crustaceans can occur for various reasons and in some cases their drivers are poorly understood. Objective: Here, we present our observations of an apparently rare massive aggregation of pelagic swimming crabs, Euphylax dovi. Methods: During a research cruise at Cocos Island ( $\left.5^{\circ} 32^{\prime} 34^{\prime \prime} \mathrm{N}, 87^{\circ} 05^{\prime} 06^{\prime} \mathrm{W}\right)$, we encountered large numbers of $E$. dovii in surface waters in the evenings of May 6-7, 2015, some of which we collected for identification prior to returning to the water. Results: Crabs of both sexes were identified, yet no females were bearing eggs. Crabs aggregated around a small dinghy used for scientific surveying from $4 \mathrm{pm}$ through $8 \mathrm{pm}$ each evening, and around our research vessel throughout the night, presumably attracted by the lights. On both occasions, the aggregation dissipated around dawn. Crabs were not seen prior to or after the two nights. Conclusions: Sea surface temperatures at Cocos during this period were markedly warm, with no perceptible thermocline down to at least $40 \mathrm{~m}$, coinciding with the onset of the 2015 El Niño event. It appears that the aggregation formed in response to El Niño conditions, yet the biological reason behind it remains unknown.
\end{abstract}

Key words: Brachyura; Eastern Tropical Pacific; El Niño; mass aggregation.

Hearn, A., Steiner, T., \& Arauz, R. (2020). A brief massive aggregation of pelagic swimming crabs Euphylax dovii (Decapoda: Portunidae) at Cocos Island, Costa Rica coincides with onset of El Niño event. Revista de Biología Tropical, 68(Suppl. 1), S289-S295.

Temporary aggregations of marine organisms occur across taxa and for many reasons, which for crustaceans may include reproduction (Allee, 1927; Nemeth, 2009), feeding (Fielder, 1970), protection from predation during ecdysis (Carlisle, 1957), migration (see Allee, 1927) and even as a form of energy conservation (Ritz, 2000). They may be triggered by climatic conditions, either predictable or otherwise. Several species of crabs are known to form swarms under certain conditions, including the Mexican red crab, Pleuroncodes planipes Stimpson 1860 off Baja California in the Eastern Tropical Pacific (Kashkina \& Kashkin, 1994), and the portunid crabs Polybius henslowii Leach, 1820 in the NE Atlantic (Gonzalez-Gurriarán, 1993) and Charybdis smithii Macleay, 1838 in the Indian Ocean (van Couwelaar, Angel, \& Madin, 1997).

A further portunid species, the pelagic swimming crab, Euphylax dovii Stimpson, 1860 (Decapoda: Brachyura: Portunidae) is found in the Eastern Tropical Pacific from Bahia de Manzanillo (Mexico) to Talcahuano, 
Chile in coastal waters and as far west as $120^{\circ} \mathrm{W}$, including the oceanic islands of Galapagos (Ecuador), Malpelo (Colombia) and Isla del Coco, often referred to in English as Cocos Island (Costa Rica) (Garth \& Stevenson, 1966; Jerde, 1970). It can be highly abundant and can dominate the benthic community along the seabed at shallow depths in some areas, e.g. the continental shelf off Colombia (Norse \& Estevez, 1977). Within this region, it is an important part of the diet of commercial fish species in the Eastern Pacific, such as yellowfin tuna, making up to $25 \%$ of stomach content volumes in some cases (Juhle, 1953; Perrin, Warner, Fiscus \& Holts, 1970). Here, we describe the occurrence of a brief but massive aggregation of E. dovii at Cocos Island National Park, and discuss potential links to the 2015 El Niño event.

\section{MATERIALS AND METHODS}

Cocos Island (Costa Rica) is a small (23.2 $\mathrm{km}^{2}$ ) tropical island located along the Cocos Ridge in the Eastern Tropical Pacific biore-

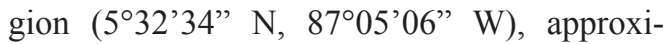
mately $500 \mathrm{~km}$ southwest of mainland Costa Rica (Fig. 1) (Cortés, 2008). The island was declared a national park in 1978 , but due to its extraordinary marine biodiversity and importance as an aggregation site for endangered hammerhead sharks and green turtles, amongst other threatened marine migratory species, this was expanded to include its marine habitats in 1991 and again in 2001. The current no-take marine reserve, covering $1997 \mathrm{~km}^{2}$, extends to a radius of 22.2 kilometers offshore around the island, and was declared a UNESCO Natural World Heritage Site in 2002 (Alvarado, Cortés, Esquivel \& Salas, 2012). As an oceanic island,

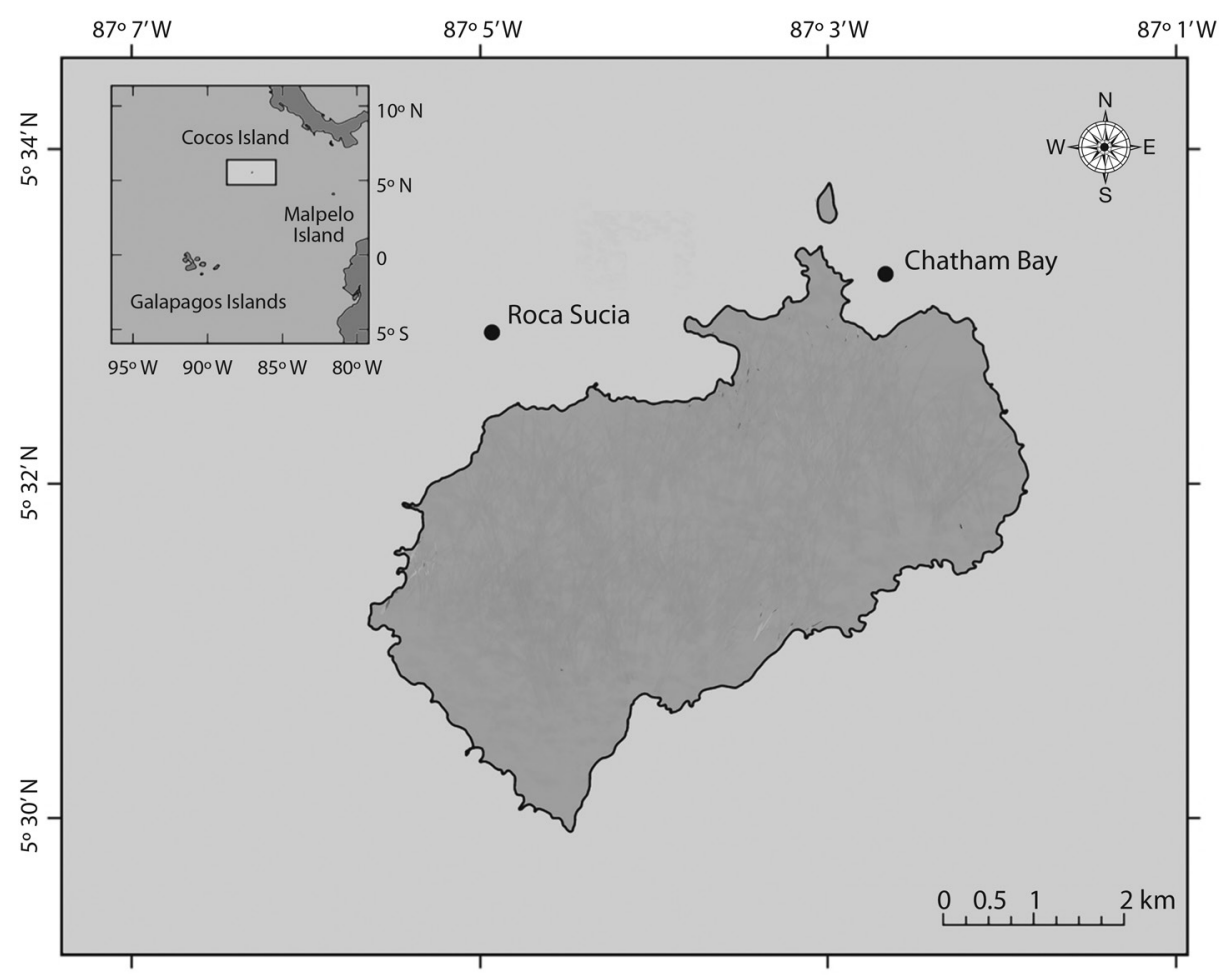

Fig. 1. Cocos Island, Costa Rica, showing locations where E. dovii aggregations were observed.

Fig. 1. Isla del Coco, Costa, con ubicaciones de los lugares de avistamiento de agregaciones de E. dovii. 
Cocos has a small shelf area $\left(300 \mathrm{~km}^{2}\right)$ beyond which depths drop rapidly to several thousand meters (Lizano, 2001). The island sits near the intersection of the Panama current and is in the path of the eastward-flowing North Equatorial Counter-Current (NECC), which is at its strongest from August to January, while in the first trimester, advection the Gulf of Papagayo brings nutrients to the island (Lizano, 2012).

In May 2015, we carried out a research expedition on board the MV Alucia, to catch and track several species of sharks thought to reside at the island (for trip report see Arauz, Steiner, Hearn, \& Antoniou, 2016). The observations described in this note, took place while fishing at night from a small inflatable dinghy. To explore the conditions at Cocos Island at the time of the aggregations, we accessed monthly sea surface temperature anomaly and daily sea surface temperature from satellite data made available at the NOAA/SWFSC Environmental Research Division.
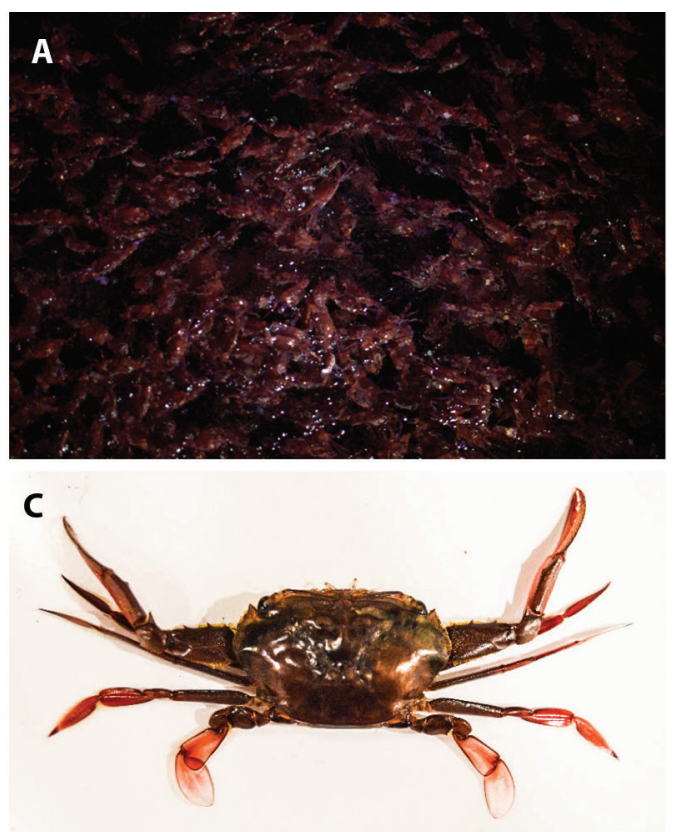

Our research vessel was anchored at Chatham Bay (Fig. 1). We fished from a small dinghy close to Roca Sucia (Fig. 1), an offshore islet off the north coast of the main island, in the evenings of May 6-9 using hook and lines (full moon that month was on May 4). Fishing activities began at approximately $4 \mathrm{pm}$ and continued past sunset to around $8 \mathrm{pm}$ each evening. After dusk, on the evenings of May 6 and 7 (but not on subsequent nights), we observed massive aggregations of reddish-purple swimming crabs from around the dinghy at Roca Sucia to the research vessel at Chatham Bay (Fig. 2). By dawn, the crabs had descended to the seabed, which was at a depth of around 30 $\mathrm{m}$ at our anchor location.

\section{RESULTS}

We brought a small number of individuals onto the boat for identification after which we
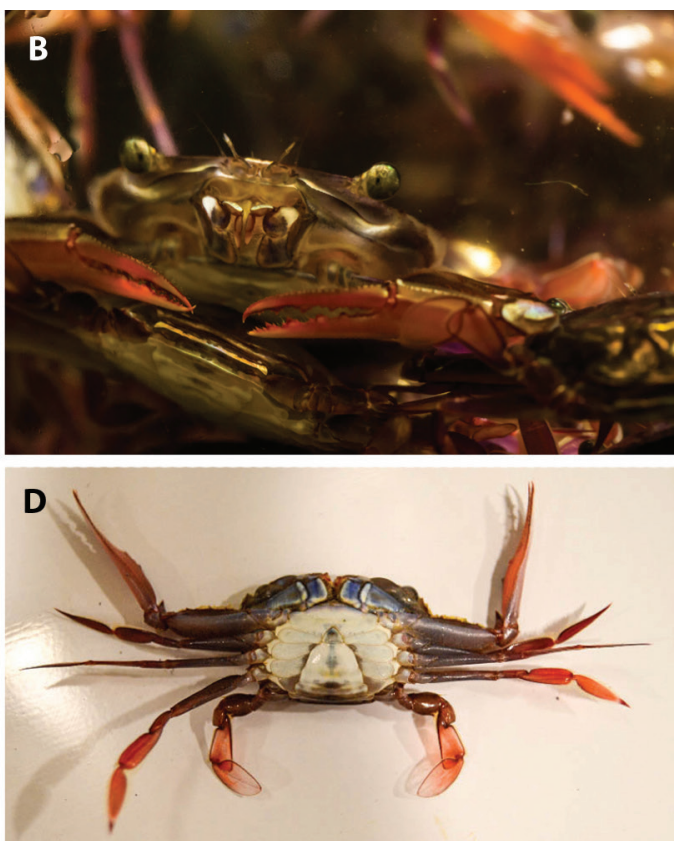

Fig. 2. Specimens of the pelagic swimming crab Euphylax dovii observed at Cocos Island. A. Aggregations of E. dovii observed at Chatham Bay. B. Close-up of E. dovii rostrum and cheliped or claw. C. Dorsal view of E. dovii. D. Ventral view of E. dovii. Photography (Ian Kellet: A, B; Alex Hearn: C, D).

Fig. 2. Especímenes del cangrejo pelágico Euphylax dovii observados en Isla del Coco. A. Agregación de E. dovii observado en Bahía Chatham. B. Vista de cerca de rostrum y tenaza de E. dovii. C. Vista dorsal de E. dovii. D. Vista ventral de E. dovii. Fotografías (Ian Kellet: A, B; Alex Hearn: C, D). 
released them back into the water. We observed individuals of both sexes. None of the females were ovigerous. Based on Garth \& Stevenson (1966) we identified the species as Euphylax dovii.

None of the science team on board, with a combined experience of $>50$ expeditions to Cocos Island since the turn of the century, had observed this phenomenon before. However, according to a local dive operator, who was also there at the time, a similar event occurred approximately a decade earlier, around 2007 (S. Blum, Undersea Hunter Group, personal communication).

The aggregation occurred approximately during the greatest positive sea surface temperature anomaly ever recorded for Cocos Island (Fig. 3a). Sea surface temperature peaked over $30^{\circ} \mathrm{C}$ in the week to the observation, but instead of dropping rapidly after this (as in the following year), temperatures remained warmer than usual throughout the next few months, with the onset of the El Niño event of 2015 (Fig. 3b).

\section{DISCUSSION}

The swarm of adult $E$. dovii of both sexes described here may be related to increased food availability around the island due to the warm conditions, or may also be a spawning event. Although $E$. dovii is a pelagic crab, here we found it at the surface in shallow coastal waters around the island at night, and on the seabed ( 20-30 m) during the day. Many species of decapod crustaceans attach their eggs to their pleopods until hatching. Spawning in portunid species appears to depend on the availability of sandy substrate - without this, eggs fail to attach. Norse \& Fox-Norse (1977) suggest that despite its pelagic life history, E. dovii has not evolved a mechanism of attachment independent of the substratum and must therefore migrate to shallow waters for spawning. Our observations may be consistent with pre-spawning aggregation behavior before settling to the seabed, which would explain why the females we collected were not ovigerous.
Onshore migrations of pelagic swimming crabs are not unique to this species. In the Indian Ocean, the portunid crab Charybdis smithii forms seasonal surface swarms that are apparently monsoon-driven (Romanov, Potier, Zamorov, \& Ménard, 2009) and migrate onshore in the month of October to form nocturnal surface swarms (van Couwelaar et al., 1997). Another portunid crab, Polybius henslowei Leach, 1820 forms surface aggregations at certain times of year in the northwest Atlantic, which are thought to be related to reproduction (Allen, 1968).

Swarming is not limited to the portunids. The Galatheid crab Pleuroncodes planipes, larvae, juveniles and early adults are planktonic its adult stage was originally thought to be entirely pelagic, as large numbers of specimens were occasionally washed up along beaches of Baja California, Mexico (Boyd, 1967). It is the most common species in the micronekton of southern California current, and is known to form dense swarms which have been hypothezised to be related to reproduction (Gomez \& Sanchez, 1997) or feeding as a response to local upwelling (Hutchings, Pitcher, Probyn, \& Bailey, 1995) or a combination of both (Robinson, Anislado, \& Lopez, 2004).

However, the swarming behavior of the above-mentioned species appear to follow some seasonal pattern. In the case we present, this is the first documented report of a massive aggregation of $E$. dovii in the Eastern Tropical Pacific since the 1997-8 El Niño event, when large aggregations of this crab were observed in bays of the western Galapagos Islands, attracted by the lights (Hickman \& Zimmerman, 1990). Similar aggregations are reported in previous years of El Niño events (Garth, 1946). Our observations took place at the start of the 2015-16 El Niño event, which developed into one of the strongest in recorded history (Jacox et al., 2016). Given the intensity of vessel-based tourism at both Galapagos and Cocos, it is unlikely that these swarms occur regularly and are simply not being observed. While reproductive purposes should not be discounted, it is hard to imagine an evolutionary 


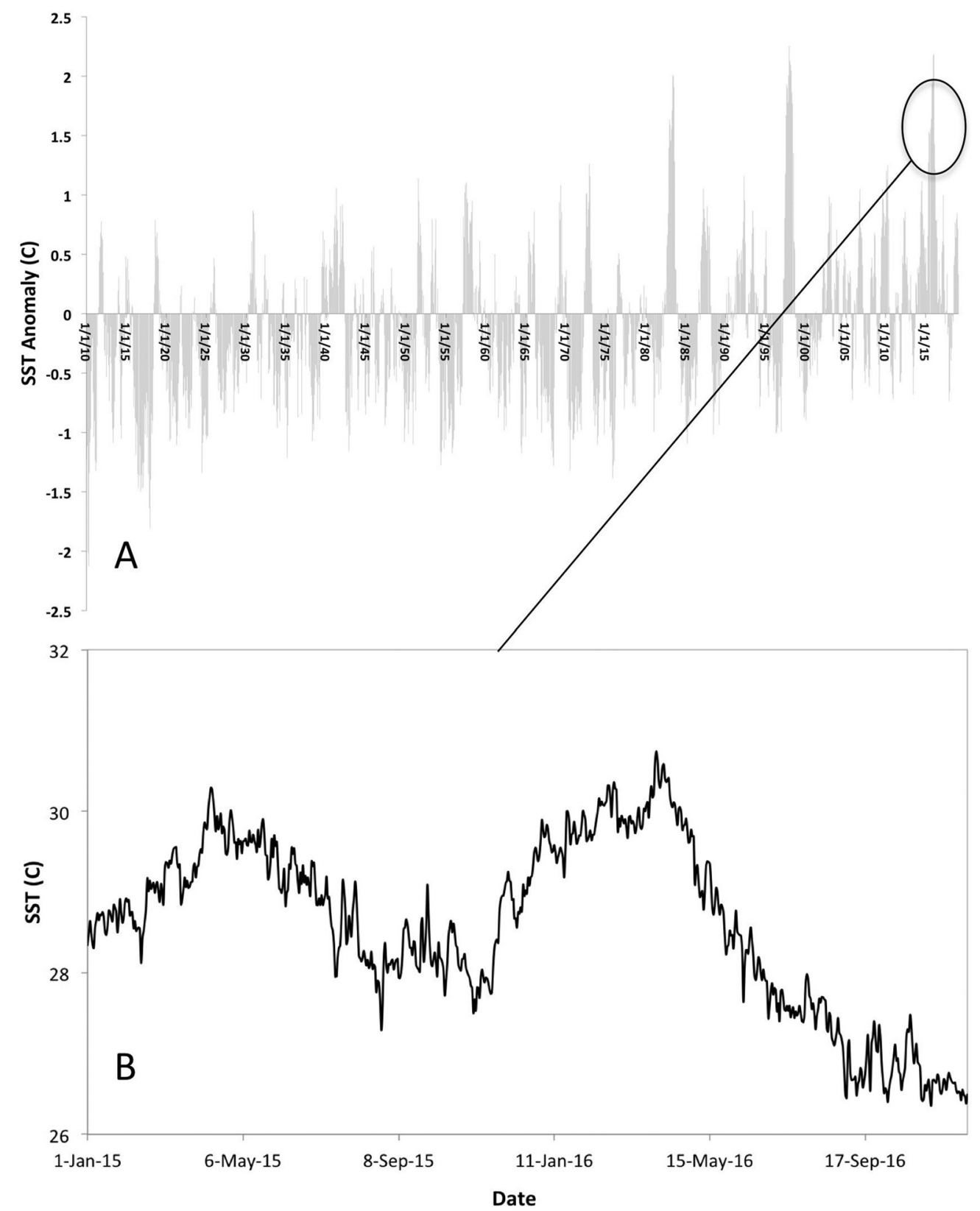

Fig. 3. A. Monthly sea surface temperature anomaly for Cocos Island from 1910-2019. B. Daily sea surface temperature at Cocos Island for 2015-16 (Data extracted from NOAA/SWFSC Environmental Research Division).

Fig. 3. A. Anomalía de la temperatura superficial mensual para isla del Coco entre 1910-2019. B. Temperatura superficial diaria para Isla del Coco para 2015-2016 (Datos extraídos de NOAA/SWFSC Environmental Research Division). 
pressure that could have led to such a strategy based on sporadic events.

Ethical statement: authors declare that they all agree with this publication and made significant contributions; that there is no conflict of interest of any kind; and that we followed all pertinent ethical and legal procedures and requirements. All financial sources are fully and clearly stated in the acknowledgements section. A signed document has been filed in the journal archives.

\section{ACKNOWLEDGEMENTS}

Thanks to the crew of MV Alucia, the Dalio Foundation, Área de Conservación Marina Cocos, Alucia Productions, and in particular to Ian Kellet and Erik Rochner for providing images and footage of the event.

\section{RESUMEN}

Una breve agregación masiva de cangrejos pelágicos Euphylax dovii (Decapoda: Portunidae) en la Isla del Coco, Costa Rica, coincide con el inicio de un evento El Niño. Introducción: Las agregaciones esporádicas de crustáceos decápodos ocurren por varias razones, y en algunos casos no se conocen los factores que las provocan. Objetivos: En esta publicación presentamos nuestras observaciones sobre un evento aparentemente no muy común, de una agregación masiva de cangrejos pelagicos Euphylax dovii. Métodos: Durante una expedición

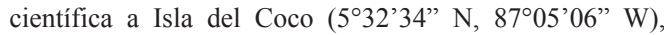
encontramos grandes cantidades de cangrejos pelágicos en las aguas superficiales en las noches del 6 al 7 de mayo, 2015. Colectamos algunos individuos para identificarlos antes de liberarlos nuevamente. Resultados: Identificamos cangrejos de ambos sexos, pero ninguna hembra en estado ovígero. Los cangrejos se agregaron alrededor de una pequeña panga que utilizamos para realizar actividades de muestreo científico entre las $4 \mathrm{pm}$ y las $8 \mathrm{pm}$ cada tarde, $\mathrm{y}$ alrededor de nuestro buque de investigación durante la noche, presumiblemente atraídos por las luces. En ambas ocasiones, la agregación disipó antes del amanecer. No se avistaron cangrejos en las noches anteriores o posteriores. Conclusiones: Las temperaturas superficiales marinas en Isla del Coco durante este periodo fueron altas, sin termoclina hasta al menos $40 \mathrm{~m}$, coincidiendo con el inicio del evento El Niño de 2015. Parece que la agregación se formó en respuesta a las condiciones del Niño, pero las razones biológicas dicha agregación no se conocen.
Palabras clave: Brachyura; Pacífico Este Tropical; El Niño; agregación masiva.

\section{REFERENCES}

Allee, W. C. (1927). Animal Aggregations. The Quarterly Review of Biology, 2, 367-398.

Allen, J. (1968). The surface swarming of Polybius henslowi [Brachyura: Portunidae]. Journal of the Marine Biological Association of the United Kingdom, 48(1), 107-111.

Alvarado, J. J., Cortés, J., Esquivel, M. F., \& Salas, E. (2012). Costa Rica's Marine Protected Areas: status and perspectives. Revista de Biología Tropical, 60(1), 129-142.

Arauz, R., Steiner, T., Hearn, A., \& Antoniou, A. (2016) Censo de los tiburones del Parque Nacional Marino Isla del Coco. Reporte Final: Diciembre 2014 - Julio 2015. San José, Costa Rica. Turtle Island Restoration Network \& Fins Attached.

Boyd, C. M. (1967) The benthic and pelagic habitats of the red crab Pleuroncodes planipes. Pacific Science, 21, 394-403.

Carlisle, D. B. (1957). On the hormonal inhibition of molting in Decapod Crustacea. Journal of the Marine Biological Association of the United Kingdom, 36, 292-307.

Cortés, J. (2008). Historia de la investigación marina de la Isla del Coco, Costa Rica. Revista de Biología Tropical, 56(Supp. 2), 1-18.

Fielder, D. R. (1970). The feeding behaviour of the sand crab Scopimera inflata (Decapoda, Ocypodidae). Journal of Zoology, 160(1), 35-49.

Garth, J. S., \& Stevenson, W. (1966). Brachyura of the Pacific coast of America, Brachyrhyncha: Portunidae. Alan Hancock Monographs in Marine Biology, 1. California, USA: Alan Hancock Foundation.

Gomez, G. J., \& Sanchez, O. C. (1997). Larval drift and population structure of Pleuroncodes planipes (Stimpson) (Crustacea: Galatheidae) off the southwest coast of Baja California. Bulletin of Marine Sciences, 61, 305-326.

Gonzalez-Gurriarán, E., Freire, J., \& Fernández, L. (1993). Geostatistical analysis of spatial distribution of Liocarcinus depurator, Macropipus tuberculatus and Polybius henslowii (Crustacea: Brachyura) over the Galician continental shelf. Marine Biology, 115, 453-461.

Hickman, C. P., \& Zimmerman, T. L. (2000). A field guide to crustaceans of Galápagos: an illustrated guidebook to the common barnacles, shrimps, lobsters, and 
crabs of the Galápagos Islands. Galapagos Marine Life Series, Sugar Spring Press, Lexington, VA, USA.

Hutchings, L., Pitcher, G. C., Probyn, T. A., \& Bailey, G. W. (1995). The chemical and biological consequences of coastal upwelling. In C. P. Summerhayes, K. C. Emeus, M. V. Angel, R. L. Smith \& B. Zeitzchel (Eds.), Upwelling in the Ocean, Modern Processes and Ancient Records (pp. 65-81). United Kingdom: Wiley.

Jacox, M. G., Hazen, E. L., Zaba, K. D., Rudnick, D. L., Edwards, C. A., Moore, A. M., \& Bograd, S. J. (2016). Impacts of the 2015-2016 El Niño on the California Current System: Early assessment and comparison to past events. Geophysical Research Letters, 43, 7072-7080.

Jerde, C. W. (1970). Further notes of the distribution of Portunus xantusii affinis and Euphylax dovii (Decapoda Brachyura, Portunidae) in the Eastern Tropical Pacific. Crustaceana, 19(1), 84-88.

Juhl, R. (1953). Notes on the feeding habits of subsurface yellowfin and bigeye tunas of the eastern tropical Pacific Ocean. California Fish \& Game, 41, 99-101.

Kashkina, A. A., \& Kashkin, N. I. (1994). Mexican red crab Pleuroncodes planipes Stimpson 1860 (Galatheidae) as an intermediate trophic link in the upwelling ecosystem along the shores of Baja California. Oceanology, 33, 502-509.

Lizano, O. G. (2001). Batimetría de la plataforma insular alrededor de la Isla del Coco, Costa Rica. Revista de Biología Tropical, 49(Suppl. 2), 163-170.

Lizano, O. G. (2012). Dinámica de aguas alrededor de la Isla del Coco, Costa Rica. Revista de Biología Tropical, 56(Suppl. 2), 31-48.

Norse, E. A., \& Estevez, M. (1977). Studies on portunid crabs from the Eastern Pacific. I. Zonation along environmental stress gradients from the coast of Colombia. Marine Biology, 40, 365-373.

Nemeth, R. S. (2009). Dynamics of Reef Fish and Decapod Crustacean Spawning Aggregations: Underlying Mechanisms, Habitat Linkages, and Trophic Interactions. In I. Nagelkerken (Ed.), Ecological Connectivity Among Tropical Coastal Ecosystems (pp. 73-134). Netherlands: Springer.

Norse, E. A., \& Fox-Norse, V. (1977). Studies on portunid crabs from the Eastern Pacific. II. Significance of the unusual distribution of Euphylax dovii. Marine Biology, 40, 374-376.

Perrin, W. F., Warner, R. R., Fiscus, C. H., \& Holts, D. B. (1970). Stomach contents of porpoise, Stenella spp., and yellowfin tuna, Thunnus albacares, in mixed-species aggregations. Fishery Bulletin, 71(4), 1077-1092.

Ritz, D. A. (2000). Is social aggregation in aquatic crustaceans a strategy to conserve energy? Canadian Journal of Fisheries and Aquatic Sciences, 57(S3), 59-67.

Robinson, C. J., Anislado, V., \& Lopez, L. (2004) Pelagic red crab (Pleuroncodes planipes) related to active upwelling sites in the California Current off the west coast of Baja California. Deep-Sea Research II, 51, 753-766.

Romanov, E., Potier, M., Zamorov, V., \& Ménard, F. (2009). The swimming crab Charybdis smithii: distribution, biology and trophic role in the pelagic ecosystem of the western Indian Ocean. Marine Biology, $156,1089-1107$.

Van Couwelaar, M., Angel, M. V., \& Madin, L. P. (1997). The distribution and biology of the swimming crab Charybdis smithii McLeay 1838 (Crustacea; Brachyura; Portunidae) in the NW Indian Ocean. DeepSea Research II, 44(6-7), 1251-1280. 